\section{References}

1. van der Meer FJM, Koster T, Vandenbroucke E, Briet E, Rosendaal FR. The Leiden Thrombophilia Study. Thromb Haemost 1997; 78: 631-5.

2. Ridker PM, Hennekens ChH, Lindpaintner K, Stampfer MJ, Eisenberg PR, Miletich JP. Mutation in the gene coding for coagulation factor V and the risk of myocardial infarction, stroke, and venous thrombosis in apparently healthy men. N Engl J Med 1995; 332: 912-7.

3. Prohaska W, Mannebach H, Schmidt M, Gleichmann U, Kleesiek K. Evidence against heterozygous coagulation factor V 1961 G to A mutation with resistance to activated protein $\mathrm{C}$ being a risk factor for coronary artery disease and myocardial infarction. J Mol Med 1995; 73: 521-4.

4. Rosendaal FR, Siscovick DS, Schwartz SM, Beverly RK, Psaty BM, Longstreth WT Jr, Raghunathan TE, Koepsell TD, Reitsma PH. Factor V Leiden (resistance to activated protein $\mathrm{C}$ ) increases the risk of myocardial infarction in young women. Blood 1997; 89: 2750.
5. Poort SR, Rosendaal FR, Reitsma PH, Bertina RM. A common genetic variation in the 3'-untranslated region of the prothrombin gene is associated with elevated plasma prothrombin levels and an increase in venous thrombosis. Blood 1996; 88: 3698-703.

6. Nachman RL. Thrombosis and atherogenesis: Molecular connections. Blood 1992; 79: 1897-906.

7. Ferraresi P, Marchetti G, Legnani C, Cavallari E, Castoldi F, Mascoli F, Ardissino D, Palareti G, Bernardi F. The heterozygous 20210 G/A prothrombin genotype is associated with early venous thrombosis in inherited thrombophilias and is not increased in frequency in artery disease. Arterioscler Thromb Vasc Biol 1997; 17: 2418-22.

8. Rosendaal FR, Siscovick DS, Schwartz SM, Psaty BM, Raghunathan TE, Vos HL. A common prothrombin variant $(20210 \mathrm{G}$ to A) increases the risk of myocardial infarction in young women. Blood 1997; 90: 1747-50.

Received August 28, 1998 Accepted after revision September 24, 1998

\title{
Simultaneous Genotyping for Factor V Leiden and Prothrombin G20210A Variant by a Multiplex PCR-SSCP Assay on Whole Blood
}

Dear Sir,

The understanding of the genetic basis for hereditary thrombophilia has been substantially expanded by the detection of common mutations in the genes for factor V (FV Leiden - G1691A) and prothrombin (G20210A mutation) associated with a remarkable increase in risk to develop thrombosis $(1,2)$. Therefore, genotyping for both factors has been included into routine diagnostic procedures. A variety of methods based on polymerase chain reaction (PCR) amplification of the corresponding gene fragments have been developed to detect either of these mutations separately. However, performing two different tests for large numbers of samples is time-consuming and cost-benefit calculations are critical, especially when considering prophylactic testing of individuals at risk. Thus, combining both mutations in a single genotyping procedure is of great practical impact. Two such approaches based on multiplex PCR and restriction analysis have been reported $(3,4)$. One of these procedures was further simplified by applying whole blood directly to the PCR reaction (4). Recently, two further assay procedures based on multiplex PCR and heteroduplex analysis (5) or on allelespecific multiplex PCR amplification (6) using isolated DNA have been described. Both test procedures allow the concomitant detection of a third possible risk factor for venous thrombosis, the methylenetetrahydrofolate reductase (MTHFR) C677T mutation.

We have developed an alternative assay for the simultaneous detection of factor V (FV) Leiden and prothrombin (PT) 20210 G/A dimorphism which can be also performed on whole blood. First, both gene fragments are amplified by multiplex PCR followed by testing for the type of alleles present by single-strand conformation polymorphism (SSCP). Primers used for the FV gene were essentially as described by Bertina et al. (1) with a slight modification in the reverse primer

Correspondence to: Prof. Dr. M. Meyer, FH Jena, FB Medizintechnik, Tatzendpromenade 1b, D-07745 Jena, Germany - Tel.: +493641643127; FAX Number: +493641 643460; E-mail: Michael.Meyer@mt.fh-jena.de (forward: 5'-GATGCCCAGTGCTTAACAAGACCA-3', reverse: 5'TGTTATC-ACACTGGTGCTAA-3'). The primers for the PT gene fragment were: 5'-GGATGGGAAATATGGCTTCTA-3' (forward nt20032-20052) and 5'-GAATAGCA-CTGGAGCATTGA-5' (reverse - nt20235-20215). Sizes of the amplification products are 268 bp for the FV gene fragment and $204 \mathrm{bp}$ for the PT fragment. For multiplex PCR, 20 pmol of each of the four primers were included into the $50 \mu \mathrm{l}$ reaction mixture containing $10 \mathrm{mmol} / \mathrm{l}$ Tris ( $\mathrm{pH} \mathrm{8.7),} 40 \mathrm{mmol} / \mathrm{l}$ $\mathrm{KCl}, 3.5 \mathrm{mmol} / \mathrm{l} \mathrm{MgCl}, 17 \mathrm{mmol} / \mathrm{l}\left(\mathrm{NH}_{4}\right)_{2} \mathrm{SO}_{4}, 0.2 \mathrm{mmol} / \mathrm{l}$ of each deoxynucleotide triphosphate (dNTP) and 1.25 units of Taq polymerase. After denaturing at $96^{\circ} \mathrm{C}$ for $10 \mathrm{~min}, 35$ cycles containing the following steps were performed: $1 \mathrm{~min}$ at $55^{\circ} \mathrm{C}, 3 \mathrm{~min}$ at $72^{\circ} \mathrm{C}, 45 \mathrm{sec}$ at $97^{\circ} \mathrm{C}$. After final extension at $72^{\circ} \mathrm{C}$ for $10 \mathrm{~min}$ samples were cooled to $4^{\circ} \mathrm{C}$. For genotype analysis by SSCP an aliquot of the PCR sample was mixed with an equal amount of formamide, heated to $95^{\circ} \mathrm{C}$ for

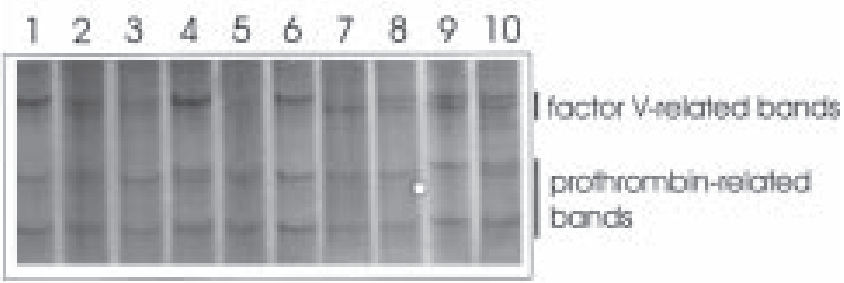

Fig. 1 Simultaneous detection of factor V Leiden mutation (G1691A) and the prothrombin G20210A variant by multiplex PCR and single-strand conformation polymorphism (SSCP) in blood samples. SSCP gel demonstrating band patterns for different genotypes. Lanes 1 and 6 - homozygotes for the two normal alleles (1691G and 20210G); lanes 2, 5 and 10 - samples heterozygous for both factor V Leiden and prothrombin 20210A variant; lanes 3 and 8 - samples heterozygous for factor $\mathrm{V}$ Leiden and homozygous for the normal prothrombin allele; lane 4 - homozygous for the normal $1691 \mathrm{G}$ allele and heterozygous for the 20210A allele; lane 7 - sample homozygous for factor V Leiden and the normal 20210G allele; lane 9 - sample from a patient heterozygous for factor $\mathrm{V}$ Leiden and homozygous for the prothrombin 20210A variant 
$5 \mathrm{~min}$ and then placed immediately on ice. A $15 \mu \mathrm{l}$-aliquot of this sample was subjected to electrophoresis at constant voltage $(120 \mathrm{~V})$ for 18 hours at room temperature in a $10 \%(\mathrm{w} / \mathrm{v})$ polyacrylamide gel, sized $190 \times 245 \times 0.6 \mathrm{~mm}$ and containing $5 \%(\mathrm{v} / \mathrm{v})$ glycerol. Gels were stained with silver using a commercial kit (PIERCE).

When establishing the assay conditions, FV and PT gene fragments were amplified separately to locate the characteristic positions of single strand bands. DNA samples genotyped previously for FV Leiden by restriction with MnlI (1) were used for this analysis. Samples homozygous for normal FV or FV Leiden, respectively, produced single bands with slightly different electrophoretic mobility, the mutated single strands migrating faster. Heterozygous samples gave the expected double band pattern. Occasionally, two additional faint bands moving slightly faster were seen, which did not interfere with the correct FV genotyping (see Fig. 1, lane 10).

The SSCP pattern for the PT gene fragment showed two clearly spaced bands for most samples; a few samples produced two closely spaced bands in the position of the slowly migrating single strand, whereas the fast migrating strands appeared somewhat diffuse. Direct sequencing on an Automated ABI 310 Genetic Analyzer revealed that the two-band pattern represents samples homozygous for the 20210G allele, samples with the three band pattern are heterozygous G/A. Then, genotyping for both risk factors after multiplex PCR was performed. SSCP patterns demonstrated, that the FV and the PT-related bands are clearly separated and can be evaluated easily (Fig. 1). A total of 380 samples mainly from patients with venous thrombosis previously tested for FV Leiden by restriction analysis (1) was genotyped by the multiplex PCR-SSCP assay (Fig. 1). There were eight samples typed heterozygous for FV Leiden by restriction analysis but normal by the SSCP assay. Repeated testing by restriction analysis and/or direct sequencing confirmed the SSCP results. Obviously, these samples had been previously misclassified because of incomplete digestion by $M n I I$. In all other cases there was complete agreement between the results of restriction enzyme- and SSCP-based assays. Genotyping for PT $20210 \mathrm{G} / \mathrm{A}$ dimorphism revealed 15 heterozygous samples and one suspected homozygote for the mutated A allele (Fig. 1, lane 9). All the suspected heterozygotes, the homozygous sample and ten normal samples were subjected to DNA sequencing. The results of the PCR-SSCP assay were confirmed in all cases.

Finally, multiplex PCR was performed using 1-4 $\mu$ l of whole blood as DNA source. As suggested by Gómez et al. (4), blood samples diluted to $20 \mu \mathrm{l}$ with $\mathrm{dd} 2 \mathrm{H} 2 \mathrm{O}$ were subjected to three temperature cycles consisting of two steps $-95^{\circ} \mathrm{C}$ for $5 \mathrm{~min}$ and $30^{\circ} \mathrm{C}$ for $30 \mathrm{sec}$ - prior to addition of PCR reagents (primers, buffer, dNTPs, ddH2O and Taq polymerase) to a final volume of $50 \mu \mathrm{l}$ and thermal cycling as described above. Best results were obtained with $2 \mu \mathrm{l}$ of blood, when PCR produced FV- and PT-related bands of almost equal intensity.

In conclusion, the combination of multiplex PCR using blood samples and SSCP screening provides a very fast, simple, reliable and low-cost alternative for the simultaneous detection of the two most common genetic risk factors for venous thrombosis. Ambiguity of test results due to incomplete digestion by restriction enzyme is excluded. In a large series of samples there was no indication of false positive results due to the potential of the SSCP method to detect other sequence variations in the vicinity of the tested mutation sites.

Michael Meyer ${ }^{1}$, Gerlinde Kutscher ${ }^{1}$, Günther Vogel ${ }^{2}$

${ }^{1}$ Faculty of Medical Engineering, University of Applied Sciences (FH) Jena, ${ }^{2}$ Center for Vascular Biology and Medicine, Faculty of Medicine of the Friedrich Schiller University Jena, Erfurt, Germany

\section{References}

1. Bertina RM, Koeleman BPC, Koster T, Rosendaal FR, Dirven RJ, de Ronde $\mathrm{H}$, van der Velden PA, Reitsma PH. Mutation in blood coagulation factor V associated with resistance to activated protein C. Nature 1994; 369: 64-7.

2. Poort SR, Rosendaal FR, Reitsma PH, Bertina RM. A common genetic variation in the 3'-untranslated region of the PT gene is associated with elevated plasma prothrombin levels and in an increase in venous thrombosis. Blood 1996; 88: 3698-703.

3. Ripoll L, Paulin D, Thomas S, Drouet LO. Multiplex PCR-mediated sitedirected mutagenesis for one-step determination of factor $\mathrm{V}$ Leiden and G20210A transition of the prothrombin gene. Thromb Haemost 1997; 90: 960-1.

4. Gómez E, van der Poel SCPAM, Jansen J, van der Reijden BA, Leuwenberg B. Rapid simultaneous screening of factor V leiden and G20210A prothrombin variant by multiplex polymerase chain reaction on whole blood. Blood 1998; 91: 2208-9.

5. Bowen DJ, Bowley S, John M, Collins PW. Factor V Leiden (G1691A), the prothrombin 3'-untranslated region variant (G20210A) and thermolabile methylenetetrahydrofolate reductase (C677T): A single genetic test genotypes all three loci - determination of frequencies in the $\mathrm{S}$. Wales population of the UK. Thromb Haemost 1998; 79: 949-54.

6. Hézard N, Cornillet-Lefebvre P, Gillot L, Potron G, Nguyen P. Multiplex ASA PCR for a simultaneous determination of factor $V$ Leiden gene, $G \rightarrow A$ 20210 prothrombin gene and $\mathrm{C} \rightarrow \mathrm{T} 677$ MTHFR gene mutations. Thromb Haemost 1998; 79: 1054-5.

Received August 7, 1998 Accepted after revision September 22, 1998 